\title{
Thinking of Russia
}

\section{Finnish Neutrality after the Cold War and the Influence of Russian Neighborhood on Finnish Cooperation with NATO}

Lucie Zimmermanová, Zdeněk Křiž, Eva Doleželová

In recent years, Finland has closely cooperated with NATO and Finnish politicians emphasize that Finland may consider joining the Alliance at any point. However, this step is unlikely in the foreseeable future. Russia's aggressive actions abroad disconcert Finland; as this article shows, even after Russia's war with Georgia and the breakout of the crisis in Ukraine, the situation is not deemed serious enough by the Finns for them to risk a serious deterioration of relations with their eastern neighbor. Rather than crossing the interests of Moscow, whose perception of the world Finland has been able uniquely to understand thanks to its historical experience, the country opts for a more complex, yet also safer, path of balancing between ever-closer cooperation with NATO, and maintaining the status of a non-member country.

Keywords: Finland, Russia, neutrality, military non-alignment, NATO.

When US President Donald Trump and his Russian counterpart, Vladimir Putin, met briefly in Helsinki in July 20I8, the Finnish president, Sauli Niinistö, told CNN that he sometimes wondered why people called his country neutral as he didn't feel neutral at all. ' A major task

Lucie Zimmermanová, Zdeněk Kříž, Eva Doleželová. Thinking of Russia. Finnish Neutrality after the Cold War and the Influence of Russian Neighborhood on Finnish Cooperation with NATO. Central European Journal of International and Security Studies I4, no. I: 9-30.

(C) 2020 CEJISS. Article is distributed under Open Access licence: Attribution NonCommercial 3.0 Unported (cc by-nc 3.0). 
for Finland will be to update its public profile [...]. As seen by the USA and Russia, Finland is no longer a "neutral" country, but an established member of the West, even if it is not a NATO member', noted the website of the public service broadcaster Yle, before the presi-

CEJISS dential summit. "Finland is an EU member and clearly belongs to the

I/2020 West [...] Finland thus is not a neutral country. Not anymore', wrote the largest-circulation Finnish daily newspaper, Helsingin Sanomat, in a commentary on the event. ${ }^{3}$ The facts confirm these statements: Finland's political leaders regularly participate in the top-level talks of NATO member states (and President Niinistö even takes part in the alliance's summits); Finland is involved in NATO military exercises, and in recent years has established close military cooperation with the USA and Sweden. In government documents and speeches abroad, Finnish politicians emphasize that the door to NATO remains open and that the country reserves the option to consider its accession to the alliance at any point.

Finland no longer wants to be considered a neutral country - and given the above, it should not be. At the same time, it adheres closely to the policy of military non-alignment. The difference between the two concepts rests in the measure of its activity in the international system and in the linkage of the country's security policy with the security structures of its allies and alliances. The term 'military non-alignment' can be understood as a subspecies of neutrality that is exclusively linked with security policy and non-membership of military organizations, without thereby limiting cooperation in other areas and on other platforms. Finns emphasize that they belong to the West, and indeed since the end of the Cold War the country has firmly embedded itself in Western structures. Describing their country as neutral can offend Finns, as it foists upon them a Cold War era geopolitical perspective, when Finland straddled the West and the East and sought to maintain an optimal balance between considering Soviet interests and pursuing an independent foreign policy. On the other hand, despite much closer cooperation than before, so far the Finns have refused to join NATO, and we believe this is because of Moscow's disapproval.

The impact of Finland potentially joining NATO is a key topic of scholarly works that address the idea. Although authors have differing views on what the ultimate consequences of such a decision would be, beyond considering the financial and military commitments the expected reaction of Moscow is among the fundamental reasons why 
experts say that Finland should not seek membership in the foreseeable future. ${ }^{4}$

Antti Sierla and Aurélie Domisse have argued that, despite Moscow's disapproval, Finland's accession to NATO might help the dialogue between Russia and the West, thanks to the country's particular historical experience with its Eastern neighbor. ${ }^{5}$ Such optimism is rare. Experts generally agree that Finland's accession to NATO would mean a serious deterioration in Finno-Russian relations. They do not, however, anticipate a military intervention by Moscow. The main arguments for these conclusions are the following: Russia's economic relations with the EU are too important to jeopardize; historically the relations between Helsinki and Moscow have been good; and Finland's membership of NATO would act as a deterrent. ${ }^{6}$ Kari Möttölä argued that it would only make sense to join the alliance if the country were under threat. As long as there is no direct security threat, there is no need to provoke Russia. ${ }^{7}$ Magnus Nordenman too does not expect Finland to join NATO in the near future. ${ }^{8}$

The security situation in the region has changed, particularly after two acts of Russian aggression: the war in Georgia and the crisis in Ukraine. These events have disconcerted the Finns, as shown by the short-term fluctuations in the otherwise long-stable public opinion with respect to NATO, closer cooperation with the alliance and the USA and recognition in official government papers of the worrying changes in the security environment. Despite this it is unlikely that Finland would seek NATO membership in the near future. The country's military non-alignment has become such an integral part of Finnish strategic thought that neither the Russo-Georgian war nor the crisis in Ukraine has pushed the Finns towards genuine consideration of membership. Paradoxically this is because Finland increasingly sees Russia as a security threat. So far, the Finns have not seen the potential gains from joining NATO as outweighing the risks of a sharp deterioration in their relations with the eastern neighbor. Proceeding from its historical experience, Finland has adopted a strategy of considering Russian security interests when deciding the future avenues of its own security policy.

The first section of this article analyses military non-alignment as part of Finland's strategic thought and observes its transformations on three events that affected the country's security situation: the end of the Cold War, the Russo-Georgian war and the crisis in Ukraine. The 
second section presents the strengthening of military cooperation between Finland and NATO, as well as between Finland, Sweden and the USA. The third section is dedicated to the Russian position on Finnish security policy and Finland's factoring in of Russian security interests.

CEJISS In the conclusion the article once again asks why, given that Finland I/202O cooperates closely with NATO, the country has not yet joined, and presents our answers to this topical question.

\section{Military non-alignment as part of Finland's strategic thought From neutrality to military non-alignment}

Finland emerged in I9I7 by emancipating itself from tsarist Russia. The main principles of its interwar policy were liberal democracy, sovereignty and, in the end, neutrality. The last was not entirely a matter of free choice, as had been the case with other Nordic countries: Finns desired foreign security cooperation that would anchor them more firmly to the West. However, prior to World War II they failed to establish relations with a great power or to build a security alliance - but not for want of trying. ${ }^{9}$ During the I930s, then, following the model of their closest ally, Sweden, they embraced a purely pragmatic neutrality. In the Finnish situation of the time, neutrality largely meant counterbalancing Russian influence. However, Finland failed to maintain an independent policy. In November 1939, it was attacked by the Red Army and drawn into World War II, out of which it emerged after much rigmarole as a former ally of Germany, vanquished by the Soviet Union.

During the Cold War Finland sought to act as a neutral country. Decisions about its foreign and security policy were nonetheless dependent on the Soviet Union. Finnish foreign policy was adjusted by the Agreement of Friendship, Cooperation, and Mutual Assistance with the Soviet Union signed in I948. In this treaty the parties pledged not to create or become involved in any alliance directed against the counterparty. In practice, throughout the Cold War this wording permitted the Finns only one foreign-policy line: neutrality. What was most important for Finland was the preamble to the agreement, in which the Soviet Union recognized Finland's determination to remain outside great-power conflict - this was explicitly requested by the Finnish delegation. ${ }^{\text {.0 }}$ Finnish politicians viewed this formulation as the Soviet recognition of Finland's neutrality. ${ }^{\text {II }}$

The termination of the agreement in March 1992 meant that Finns regained full sovereignty and opened the path towards a new inter- 
pretation of neutrality. After a long discussion that unfolded against the background of making Finland's accession to the European Communities compatible with the principle of neutrality, in 1992 the government defined Finland's foreign policy strategy as a combination of independent defense and military non-alignment. ${ }^{\mathrm{I2}}$ This implied a significant shift in strategic thought as a whole. Finns decided officially to step out of the grey zone or no man's land, where they had been throughout the Cold War as part of the so-called Finlandization, and openly to avow Western political structures. ${ }^{13}$ Finland did not express an interest in joining NATO in the early 1990 os, ${ }^{14}$ but in 1994 signed up for the Partnership for Peace program. Its involvement was intended to strengthen Europe's security and the country's determination to participate only in peacekeeping and humanitarian operations was explicitly noted. ${ }^{15}$ Throughout the I990s, the Finns consistently strengthened their relations with NATO and became involved in several of its crisis management operations. ${ }^{16}$ At the same time they repeatedly emphasized in international forums that though they were not seeking membership at that time, they would like to have the option in the future. ${ }^{17}$ Finland's close cooperation with NATO confirmed the shift in the country's policy from neutrality to military non-alignment.

\section{Military non-alignment in the context of the Russo-Georgian war}

Before the Russo-Georgian war, Finland's accession to NATO was not on the table. There was not much support for it among the political parties or Finnish citizens. Political leaders tended to emphasize the negative aspects of accession. From 2006, only the National Coalition Party (Kansallinen Kokoomus, abbreviated Kok.) - the strongest pro-Atlantic force in Finnish politics - openly supported accession. ${ }^{18}$ The president of Finland at the time, Tarja Halonen of the Social Democratic Party of Finland (Suomen Sosialidemokraattinen Puolue, SPD), who by virtue of her office exerted strong influence over Finnish foreign policy throughout her mandate from 2000 to 2012, strongly opposed accession. ${ }^{19}$ Her position chimed in with the popular mood. In 2002, nearly 70 percent of Finns said that the country should not join the alliance. ${ }^{20}$ The accession of the Baltic countries to NATO did not cause a shift in popular opinion in Finland. In 2004, 65 percent of the population agreed that the policy of military non-alignment should be maintained. $^{2 \Gamma}$ 
Although the Georgian crisis revived the Finnish security discussion, it did not bring new arguments. On the one hand, the crisis was used to emphasize the urgency of a clear decision about the country's relationship with NATO. On the other, political parties did not

CEIISS become more involved in steering the social debate, nor in shifting I/2020 popular opinion towards support for accession. ${ }^{22}$

An official government report on Finnish security and defense policy from 2009 did not consider increased tension or aggression in neighboring areas impossible, but also did not anticipate direct military pressure or aggression against Finland. The report noted the findings of the Parliamentary Security Policy Monitoring Group which concluded that the foundations of Finnish security policy needed no substantial change. The document also stated that "from now on, strong grounds exist for considering Finland's membership of NATO. As regards a decision on possible membership, broad political consensus is essential, and it is important to take public opinion into consideration." ${ }^{23}$

The approach taken by Finnish parliamentary parties was unchanged by the Georgian crisis. The National Coalition Party continued to be the main supporter of the country's joining NATO, while center-left parties took a negative stance towards participation in military alliances. ${ }^{24}$

As far as public opinion was concerned, there was a sudden decrease in the number of opponents to Finland's joining NATO in 2008, but the number of supporters did not increase; rather it was the number of the undecided that did. The numbers of those for and against membership were about equal: about a third of those polled thought that Finland should join NATO, while a third was against. The remaining third did not know with which opinion to side. ${ }^{25}$ Opinion polls do not indicate significant shifts in popular opinion of Russia or security in the aftermath of the Russo-Georgian war. The Finns started to view the long-term prospects of security somewhat more negatively. A third of the population thought that the security situation over the next ten years would become 'more threatening' to Finland - in 2007, 22 percent expressed this view. More than half thought that the situation would remain the same and only 6 percent thought it would improve. Those who expected a deterioration were then asked about the causes of increased security threats; most answers were linked with Russian military activities, including the Georgian crisis (but also included 
fears of Russia arming, nuclear weapons and Russia's relations with the Baltic countries. $)^{26}$

If the Georgian crisis stimulated Finnish politicians to think about NATO accession, public opinion remained consistent - in 2009 the number of those opposing it started to increase again - and the official government line on defense and security did not change much in the subsequent years. A 2012 government report on security and defense policy noted that Finland was not a member of any military alliance and emphasized that defense cooperation did not imply any change in the fundamental security strategy. ${ }^{27}$ After a brief scare caused by Russian aggression in Georgia, Finland decided to stick with military non-alignment. Joining NATO remained a purely theoretical option.

\section{Military non-alignment in the context of the crisis in Ukraine}

The crisis in Ukraine, the increased military presence of Moscow in the Baltic and more and more conspicuous Russian activities in northern Europe - from maritime incidents to airspace violations - disturbed Finnish politicians across the board. ${ }^{28}$ Security policy became a chief issue of campaigning prior to the 2015 parliamentary elections, but rather than NATO membership it was the increases in the defense budget that were discussed. A coalition government emerged out of the election, consisting of three parties: the centrist, liberal Centre Party of Finland (Suomen Keskusta, Kesk.); the populist and nationalist True Finns (Perussuomalaiset, PS); and the center-right National Coalition Party. ${ }^{29}$ The True Finns, who strongly criticized the EU and NATO, obtained the posts of foreign and defense ministers in the new government..$^{30} 2017$, about half of the PS members of parliament, who tended to be more conservatively-minded, split off (including the two ministers) and founded a center-right Blue Reform party (Sininen tulevaisuus, Sin.)

Today, the left-wing SPD is the strongest party of the opposition. Of the government parties, only the National Coalition Party supports NATO accession openly, but does not make the issue its priority. ${ }^{3 \mathrm{~A}}$ Also supporting accession in parliament is the Swedish People's Party of Finland (Suomen ruotsalainen kansanpuolue, abbreviated RKP in Finnish and SFP in Swedish), which has few seats. ${ }^{32}$ The overwhelming majority of parliamentary parties continue to oppose Finland's accession to NATO, most often citing popular disapproval of the idea. ${ }^{33}$ 
Despite the events unfolding in the region, the center-right government has so far stuck to the policy of military non-alignment. The most recent Finnish government report on defense policy of July 2017 noted that following the conflict in eastern Ukraine the security situation in

CEJISS Finland's neighborhood deteriorated and military tensions in the Bal$\mathrm{I} / 2020$ tic increased. On the other hand, improvements in military readiness and the increased defense budgets of the states in the region were seen as positive. The document articulates Finland's current relationship with NATO as follows: 'Finland is a country which does not belong to any military alliance. It carries out practical cooperation with NATO and continues to maintain the option to seek NATO membership. ${ }^{34}$

An analysis of the anticipated security situation of Finland over the next two decades (Defense Perspectives in the 2030s), published in June by the Finnish Ministry of Defense, makes similar points. Tensions in the region have increased. The use of another state's force against Finland cannot presently be ruled out, nor can one assume that were a conflict to flare up near its borders, Finland would be able to avoid it. In this respect, Finland seeks close international cooperation in providing security to northern Europe and the Baltic region. ${ }^{35}$ The document emphasizes the increasing significance of international cooperation for Finnish national defense capabilities. In a long-term perspective, it describes these partners as the most important: the EU, NATO, NORDEFCO, Sweden and the USA, and, by extension, all EU and NATO member countries. Finland will largely use its partnership with NATO to reinforce its own defenses. The analysis argues that Finland's potential joining of NATO will depend on several factors: Finland's evaluations of its own security situation; the alliance's willingness to admit new members; and the results of an analysis of the evolving international security situation by member countries. ${ }^{36}$ Russia is not explicitly mentioned as a factor impacting the Finnish decision about NATO accession.

Focusing now on public opinion, the position of most Finns has been to maintain military non-alignment even after the Russian aggression in Ukraine, though opinion polls show a slow increase in the proportion of the undecided and a decrease in the number of opponents to Finland's joining NATO. Between the Georgian war and the crises in Ukraine, the opponents of accession stood at 70 percent of the population, a proportion that decreased to 60 percent after 2014 . By contrast, the number of voices supporting Finnish membership of 
NATO jumped by nine percentage points in 20I4, though remaining a minority position. It decreased gradually over the following years. ${ }^{37}$ However, most Finns would agree with membership if their political leaders were unified in supporting it. ${ }^{8}$ According to an autumn 2017 poll by the Ministry of Defense, more than 60 percent were against, 22 percent were for and I7 percent had no opinion on Finland's NATO membership. ${ }^{39}$ A survey by the largest-circulation Finnish daily newspaper, Helsingin Sanomat, in November 2017 had 59 percent of respondents against joining NATO; 22 percent supporting membership in the USA-led military alliance; and i9 percent not yet decided. ${ }^{40} \mathrm{In}$ another poll, by the public-service broadcaster Yle in December 20I7, 53 percent of Finns were against their country joining NATO, I9 percent were for and nearly 28 percent were undecided. ${ }^{4 \mathrm{I}}$ More recent data by the dailies Uuusi Suomi and Iltalehti offer similar figures: 20 percent of the polled supporting Finland's joining NATO, 50 percent against, 30 percent with no opinion. However, if the president were to recommend accession, 42 percent of the last poll would support the decision..$^{42}$

Evolution of public opinion as concerned with maintaining military non-alignment was subject to the same trend. After the beginning of the crisis in Ukraine, the support for this foreign-policy line decreased (from nearly 70 percent in 2014 to less than 60 percent in 2015), but it was still supported by more than half of Finns and the numbers of those against were minimal. ${ }^{43}$

The presidential election held in January 2018 was an important indicator of public opinion as well as of the state of the security-policy debate in Finland. The only presidential candidate openly supporting joining NATO was Nils Torvalds (RKP). He placed last, taking I.5 percent of the vote, while the incumbent, Sauli Niinistö, was declared the clear winner in the very first round. Incidentally, the turnout was the lowest since the introduction of direct election, testifying to the fact that most Finns wished for continuity in security policy, i.e. rejected joining NATO while maintaining close security cooperation with the alliance, the EU and especially Sweden, as well as keeping an active dialogue open with Russia. ${ }^{44}$

\section{The development of military cooperation between Finland and its Western partners}

In matters of security, Finland cooperates widely - both bilaterally and multilaterally. The Finns combine an assertive, yet careful, foreign pol- 
icy towards Russia with close cooperation with NATO, while at the same time developing security collaborations with other countries and organizations outside the immediate structures of the alliance. Matti Pessu of the Finnish Institute of International Affairs (FIIA) has gone

CEJISS as far as to question whether Finland still is a militarily non-alignment I/202O county, given the substantial strengthening of the networks of its bilateral relations since the crisis in Ukraine. ${ }^{45}$

Finland chiefly cooperates with Sweden and the United States. Multilaterally, the Nordic Defense Cooperation (NORDEFCO) platform is important. Last but not least, the Finns cooperate with the EU's Common Security and Defense Policy.

The evolution of military cooperation between Finland and NATO Finland started to cooperate with NATO in 1994, having joined the Partnership for Peace (PfP). At a 2014 NATO summit in Wales, Finland took a step to deepen its collaboration by joining an individual program, thus becoming an "Enhanced Opportunities Partner." In 20I7, the modus was extended for another three years.

Since the mid-I990s, Finland has participated in NATO joint exercises and in its operations: IFOR/SFOR in Bosnia and Herzegovina, K-FOR in Kosovo and ISAF/Resolute Support in Afghanistan. The Finns are also involved in the training and education of NATO soldiers and in special innovative platforms such as Strategic Airlift Capability, Smart Defense and NATO Response Force. ${ }^{46}$

Finland's top leaders take part in meetings concerned with security in the Baltic region and northern Europe in the " $29+2$ " format (NATO member states plus Finland and Sweden) and President Niinistö goes to alliance summits. It is sometimes hard to tell where the boundary between NATO members and non-members is, when one looks at Finland.

\section{The evolution of military cooperation between Finland, Sweden and the USA}

Military cooperation between Finland and Sweden has a long history. In recent years its importance has increased, as the security situation in the region, viewed from the points of view of the Finns and Swedes, has deteriorated. The countries also cooperate in respect of NATO: for Finland, there would be little point in joining the alliance if Sweden were not to do so as well, as geographically the former country would 
be practically cut off from other member countries. The importance of Finno-American relations in the domain of security is also growing. The support granted by the USA to Finland has long been one of the chief arguments of Finns who press for their country to join NATO. While Finns will not find the resolve to join the alliance for some time yet, they have decided to build closer links with the USA without any delay.

Lucie

In early 2014, the then minister of defense, Carl Haglund, described strong bilateral relations with the USA and an active partnership with NATO as the two crucial security collaborations Finland had..$^{47}$ The effectiveness of this approach has been confirmed by security experts Stefan Forss and Pekka Holopainen, who described strong security cooperation among Nordic countries, supported by US security guarantees 'in whatever form they may take', as key to stabilizing the security situation in the Baltic after the crisis in Ukraine..$^{8}$ In this respect, since the outbreak of the crisis, the discussion about Finland's security policy has followed the main argument by the proponents of NATO membership, employed ever since the early zooos: close cooperation with the USA.

Finland has responded to the unrest created by Russian military activities outside their own territory by enhanced cooperation with partners from abroad. Since 20I6, the Finnish and Swedish air forces have held extensive exercises together. ${ }^{49}$ For the first time in 15 years, in summer 2017, a bilateral meeting between the presidents of the USA and Finland took place when Sauli Niinistö visited the White House. One of the main matters under discussion was security. ${ }^{50}$ In autumn 2017, Defense Minister Jussi Niinistö (Sin.) announced a plan to undertake large-scale military maneuvers in Finland - to which partner countries of the region as well as the USA would be invited - and described the official justification for the exercises as follows: 'It is important for the defense forces to have the preparedness to accept international assistance if we are faced with a crisis'. Sweden almost immediately confirmed that it would take part. However, the project is still at the planning stage and the maneuvers will take place in 2020 at the earliest. ${ }^{\mathrm{I}}$

In November 20I7, the defense ministers of Finland, Sweden and the United States met in Helsinki to discuss the options for closer collaboration between their countries. As they all already had bilateral agreements, their meeting was about giving their cooperation a concrete shape in view of the contemporary security situation in the Baltic.52 
Subsequently, in May 2018, a Trilateral Statement of Intent was signed. The document's aim is to enhance three-way cooperation in defense, including strengthening 'the strategic partnership between the EU and NATO'53 The statement is not legally binding. Finnish Defense

CEJISS Minister Niinistö denies that it is a preliminary step towards NATO I/202O accession. ${ }^{54}$ Rather, it is a declaration of foreign-security belonging of the two Nordic countries, as well as of the US security interests in the Baltic Sea region. According to Salonius-Pasternak, a Finnish security expert, the statement creates the conditions for a greater US presence in Finnish and Swedish security issues. In practical terms, it will also facilitate the conduct of joint military exercises. 55 The signatories make no effort to hide the fact that the statement is a response to Russia's aggressive foreign policy..$^{6}$

\section{Russia, Finland and neutrality}

Russia's position on the shifts in Finnish military policy

NATO enlargement has long been seen in Russia as a process that is incompatible with Russian security interests. The coming together of Finland and NATO and discussion about Finland possibly joining the alliance have long been viewed negatively in Russia. In 20I6, Russian Foreign Minister Lavrov said in this context that 'were Finland to join the anti-Russian actions', Russia would have to respond adequately.57 In July 2or6, Vladimir Putin declared that if Finland joined NATO, a repositioning of Russian armed forces would follow..$^{8}$ In the same year an expert commission concluded:

Russia will attempt to thwart any move by Finland or Sweden to join NATO. The historical record of previous NATO enlargements, despite the fact that Finland is not viewed by Russia in the same light as Ukraine or Georgia, indicates that political and economic reactions may be strong, even harsh, notably during the transition phase. Even while stopping short of the use of force, specific counter-measures would be difficult to predict. ${ }^{59}$

This Russian position has remained essentially unchanged since 2016. During his August 2018 visit to Finland, President Putin repeated that Russia disapproves of Finland's getting closer to NATO.${ }^{60}$ Overall, the Russian approach towards Finland can be seen as a combination of two strategies: one of intimidation, the other of reassurance; rather than an application solely of the reassurance strategy. 
Generally speaking, Russia considers Finland's possible NATO membership a 'red line' and makes its position quite clear. This is not a purely military question. Russia has invested a lot of political capital in the 'containment' of Finland's potential NATO membership, and if Finland were to join the alliance it would be a political defeat for Russia of the first magnitude. Yet it seems that Russia has many fewer reservations about enhanced cooperation between NATO and Finland, military cooperation included, as long as the country does not actually join NATO. Bergquist, Heisbourg, Nyberg and Tiilikainen believe that the Russian strategy that aims to prevent countries joining NATO a strategy that is based on intimidation rather than reassurance - is counterproductive today but is fully in keeping with the historical Russian and Soviet political culture. ${ }^{6 r}$

\section{Finland's considerations of Russian security interests}

Our main argument is that Finnish strategic thought has embraced the practice of considering Russian security interests to such an extent that Finland's abandonment of military non-alignment (and hence also joining NATO) are very unlikely. The Finns learned to anticipate Russian responses to their own security policy during the Cold War, when a policy of placating a suspicious Kremlin helped them to maintain some space to maneuver in at least some policy areas and retain a degree of sovereignty. Presumably, the effort not to provoke Russia was one of the reasons the Finns did not consider joining NATO in the I990s, as the same motive can be discerned behind the Finnish decision to remain outside the alliance today.

The Finns have also addressed the Russian question in official government reports on defense and security. A 2012 report noted that Russia's foreign policy, and also its domestic developments in terms of democracy and the transformation of its armed forces, impact the security situation in Finland's vicinity as much as Finnish foreign policy. The government pointed out the Russian understanding of NATO enlargement as a political and military issue. From the viewpoint of Moscow, enlargement weakens its efforts to achieve a multi-polar international system, and threatens the Russian sphere of influence. ${ }^{62}$ In a 2016 report, Finland's increasing disquiet over Russia's aggressive policy was expressed as follows: 'The security policy environment of Finland, a member of the Western community, has transformed. A more tense security situation in Europe and the Baltic Sea region 
will directly impact Finland. The use or threat of military force against Finland cannot be excluded., ${ }^{63}$

Although the document described NATO as a 'stabilizing influence in the Baltic Sea region', a decision about Finland's membership would CEJISS require extensive debate and careful consideration of all the conseI/202O quences. ${ }^{64}$

The most recent Finnish government report on defense policy, dated July 20I7, noted that the strategic importance of the region has increased. There has also been increased military activity in the Artic, as the Kola Peninsula is a place of strategic importance for Russia, which keeps its nuclear weapons there. The Finns see Russia's activities as serving its efforts to reinforce its great-power status and to establish a security regime based on spheres of influence. It proved that Russia is able to reach strategic decisions quickly and does not hesitate to use military force to achieve its objectives. ${ }^{65}$

Finland responds to Russian activities by cooperating more closely with its partners, especially Sweden and the USA, but also NATO. It does not, however, intend to take the decisive step of seeking full membership of the alliance for now. One of the factors informing Finland's careful approach is its important energy cooperation with Russia. Finland imports nearly two-thirds of its primary energy sources and Russia is the most important supplier. Finland takes active measures to improve its energy security and to increase its self-sufficiency, but this is a long-term process that could give the country significantly greater energy independence by 2030 at the earliest. ${ }^{66}$ Even the most vocal advocates of NATO accession have to pay heed to public opinion, which remains opposed to the idea, largely due to fears over the Russian response. In a 2016 opinion poll, most of the Finns who rejected NATO accession cited their country's proximity to Russia as a justification for their response. They thought that membership of the alliance would be an unwarranted provocation. ${ }^{67}$ However, most Finns view military cooperation with NATO and the USA positively. ${ }^{68}$ They see Russia not just as the reason that joining NATO would not be a sensible decision for their country, but also as the main threat from which their cooperation with the alliance and the USA should defend them. A poll by the dailies Uuusi Suomi and Iltalehti published in June 2018 revealed that nearly half of Finns support more training of their armed forces with their USA and NATO counterparts as a measure against "possible Russian threat." ${ }^{69}$ 
The fundamental line of Finnish foreign policy is to maintain good relations with the East, to gradually strengthen links with the West, and to keep the largest possible space for maneuvers. The crisis in Ukraine has spurred a discussion as to whether this line can be maintained..$^{70}$ Some experts believe that in the contemporary situation it is military non-alignment that best serves Finnish interests; ${ }^{71}$ others see the potential enlargement of NATO in Scandinavia as an important strengthening of the alliance. ${ }^{72}$ As we have shown above, the prevailing opinion among scholars and politicians alike is that Finland's accession to NATO would be too risky, as it would imply a severe cooling of relations with Moscow, at the very least. 'The Russians made it quite clear that when they look across the border now, they see the Finns. If we were in NATO, they would see enemies. That's their position,' is how President Niinistö summed up the Russian view of Finland's potential membership of the alliance in an interview with a Frankfurter Allgemeine Zeitung journalist in September 2018.73

\section{Conclusion}

Having sought neutrality for several decades, after the end of the Cold War Finland embraced a policy of military non-alignment. This reinterpretation of the traditional understanding of neutrality has allowed the country to become openly involved in the West's political, economic and military structures, without thereby provoking Russia too much.

We believe that Finland's consideration of Russian interests and of the Russian interpretation of the security situation on its western border is the main reason why Finland opts for this difficult balancing act, involving ever closer cooperation with NATO and the USA; maintaining NATO non-member status; and emphasizing that the option of joining the alliance is always there. The experts and public opinion alike believe that joining NATO would be too risky. Few think that it would result in an outright military conflict, but given the historical contact and contention between Finland and Russia, even the risk of a sharp deterioration in relations with the neighboring power is just too great - even more so at a time when, by adopting modern forms of non-direct combat, Russia is working to destabilize democracy in Europe and beyond.

Russia's actions in Georgia, Ukraine and the Baltic region disturb Finland. However, thanks to their historical and geographic proximity, 
the Finns have a unique understanding of the Russian perception of the world, and hence their response so far to their increasing feeling that their security is under threat has not been a proclamation that they would seek NATO membership - an approach that might make

CEJISS sense to some in the current situation. Instead of openly embracing I/202O a strong defense structure, they carefully build links with individual partner countries, or focus on groups such as NORDEFCO that are more palatable to Russia.

On the other hand, cooperation between Finland and NATO is closer than ever. The Finns participate in training military personnel and exercises with member states; share information; and have access to decision-making processes thanks to ' $29+2$ ' format meetings. Finland is represented in the alliance's peace-keeping missions and has a permanent mission to NATO in Brussels; the head of state participates in the annual summits of the alliance. Indeed, an uninitiated observer might be surprised to learn that Finland is not a full NATO member. Some experts even question whether Finland can still be considered a militarily non-aligned country.

Finland's political leaders, however, do not question that. Emerging out of Finnish attempts at neutrality in an environment that was strongly deformed by its proximity to an ideologically entirely incompatible superpower, military non-alignment has embedded itself firmly into Finnish strategic thought. For decades, a policy of considering Russian interests when formulating their own security policy has paid off for Finland. So far there has not been a big enough shock in the international arena for them to want to change any of it.

LUCIE Zimmermanová and ZdenĚK KŘižz are affiliated to the Faculty of Social Studies, Masaryk University, Brno, and may be reached at zimmermanoval@mail.muni.cz or 37415@mail.muni.cz respectively. Eva Doleželová is a graduate from Masaryk University and may be reached at399387@mail.muni.cz.

\section{Endnotes}

I Christiane Amanpour (2018), 'Exclusive: Finland President on Helsinki Summit,' CNN, I6 July, available at: <https://edition.cnn.com/videos/ world/2or8/o7/I6/intv-finland-russia-putin-trump-america-sauli- 
niinist.cnn> (accessed I2 August 2018); Heta Hassinen (20I8), 'Näin kärkipoliitikot kommentoivat Trumpin ja Putinin tapaamista - Petteri Orpo tviittaili naisten oikeuksista ja ilmastonmuutoksesta: 'Olemme valinneet puolemme', Helsingin Sanomat, I6 July, available at: <https:// www.hs.fi/politiikka/art-2000005758236.html> (accessed I2 August 20I8).

2 Mika Mäkeläinen (20I8), 'Toimittajalta: Miksi Suomen ei kannattaisi toivoa Trumpin ja Putinin huippukokousta,' Yle, 27 June, available at: <https://yle.fi/uutiset/3-I027689I> (accessed 23 September 2018).

3 Marko Junkkari (2018), 'Suomi oli eilen koko maailman huomion keskipiste, mutta oliko siitä hyötyä?' Helsingin Sanomat, I7 July, available at: <https://www.hs.fi/politiikka/art-2000005759293.html> (accessed 23 September 2018).

4 Charly Salonius-Pasternak (ed.) (2007), From protecting some to securing many: NATO's journey from a military alliance to a security manager, Helsinki: The Finnish Institute of International Affairs, available at: <https://www.files.ethz.ch/isn/46190/200712_From_Protecting Some.pdf> (accessed 29 April 2018); Antti Sierla (2007), Effects of Finland's possible Nato membership, Helsinki: Ministry of Foreign Affairs of Finland, available at: <http://formin.finland.fi/public/default.aspx?co ntentid=32444I\&contentlan=2\&culture $=e n-U S>$ (accessed 29 April 2018).

5 Sierla (2007); Aurélie Domisse (2016), Enlargement to the North? Sweden, Finland and NATO, Konrad Adenauer Stiftung.

6 Salonius-Pasternak(2007),pp.67-68; MatsBergquistetal.(2016), TheEffects of Finland's Possible NATO Membership: An Assessment, Helsinki: Ministry for Foreign Affairs of Finland, p. 47, available at: <www.finlandnato.org/ public/download.aspx?ID=I67886\&GUID=\%7B848I3A23-322E-4EIA993A-EBI5C44A3D67\%7D> (accessed 30 October 2018).

7 Kari Möttölä (200I), 'Finland, the European Union and NATO Implications for Security and Defence,' in Erich Reiter and Heinz Gärtner (eds.) Small States and Alliances, Heidelberg: Physica-Verlag.

8 Magnus Nordenman (2014), 'On the Transatlantic Edge,' The RUSI Journal 159 (3): 46-52. doi: I0.1080/03071847.2014.928002.

9 D. G. Kirby (1979), Finland in the Twentieth Century: A History and an Interpretation, Minneapolis: University of Minnesota Press, pp. III-II6.

Io John Lukacs (I992), 'Finland Vindicated,' Foreign Affairs 50(4); Heinz Gärtner (ed.) (2017), Engaged Neutrality: An Evolved Approach to the Cold War, Lanham: Lexington Books, p. 22.

II Janie Leatherman, (2003), From Cold War to Democratic Peace: Third Parties, Peaceful Change, and the OSCE, Syracuse, N.Y.: Syracuse University Press, p. 79; Finnish Institute of International Affairs (2018) 'Archive and Chronology of Finnish Foreign Policy, EILEN,' <https:// www.eilen.fi/en/> (accessed 29 April 20I8).

I2 Hannu Himanen (2003), 'Finland,' in Hanna Ojanen (ed.) Neutrality and non-alignment in Europe today, Helsinki: Finnish Institute of International Affairs, pp. I9-26, available at: <https://www.files.ethz.ch/isn/10696/ fiia_neutrality.pdf> (accessed 30 October 2018); Teemu Palosaari (2013), Neither neutral nor non-aligned: The Europeanization of Finland's foreign and security policy, Helsinki: The Finnish Institute of International Affairs, available at: <https://storage.googleapis.com/upi-live/20I7/oI/ffppo3.pdf> (accessed 30 October 20I8); Finnish Institute of International Affairs (20I8). 
I3 Finlandization meant the subservience and dependence of Finnish policy (not just foreign policy) on the Soviet Union, in an attempt to maintain good neighborly relations with both the East and the West and, at the same time, to derive the maximum possible profit from the extraordinary geopolitical situation. The social consequences of this policy were wideranging. In Finland the expression continues to be seen as pejorative. For more detail see e.g. Tapio Juntunen (2017), 'Helsinki Syndrome: The Parachronistic Renaissance of Finlandization in International Politics,' New Perspectives 25 (I): 55-88, available at: <http://perspectives.iir. $\mathrm{cz} /$ download/helsinki-syndrome-the-parachronistic-renaissance-offinlandization-in-international-politics/> (accessed 25 August 2018).

I4 Himanen (2003), p. 26.

I5 Finnish Institute of International Affairs (20I8).

I6 Hanna Ojanen (2000), Participation and Influence: Finland, Sweden and the Post-Amsterdam Development of the CFSP, Paris: Institute for Security Studies - Western European Union, available at: <https:// www.iss.europa.eu/sites/default/files/EUISSFiles/occoII.pdf> (accessed 29 April 2018); Prime Minister's Office (2004), 'Finnish Security and Defence Policy 2004, p. 65, <https://www.defmin.fi/files/3II/2574_216o_ English_White_paper_2004_I_.pdf $>$ (accessed 30 October 20I8).

I7 Finnish Institute of International Affairs (20I8).

I8 Yle (2007), 'Salolainen: Price of NATO Membership Increasing,' <https:// yle.fi/uutiset/osasto/news/salolainen_price_of_nato_membership_ increasing/5814200> (accessed 29 April 2018).

I9 Henrik Brors (2009), 'Ansökan till Nato skjuts upp', Dagens Nyheter, 20 January, available at: <https://www.dn.se/nyheter/varlden/ansokantill-nato-skjuts-upp/> (accessed 6 May 2018); Yle (2007).

20 Ministry of Defense (2003), 'Bulletins and Reports I/2002,'<Iurl.cz/ wtolU> (accessed 29 April 20I8).

2I Ministry of Defense (2004), 'The majority of Finns are in favour of military non-alliance. The ABDI survey 27.I.2004,'< Iurl.cz/mtolf $>$ (accessed 3I October 20I8).

22 Teresa Åhman (2009), Nato-debatten i Finland. Mellan säkerhet, inflytande och identitet, Stockholm: FOI, Swedish Defence Research Agency, p. 9, available at: <https://www.foi.se/rapportsammanfattning? reportNo=FOI-R--2719--SE Io $>$ (accessed 29 April 2018).

23 Prime Minister's Office (2009), 'Finnish Security and Defence Policy 2009,'p. 8I, <https://www.files.ethz.ch/isn/I56933/Finland_English-2009. pdf $>$ (accessed 30 October 20I8).

24 Leo G. Michel (20II), Finland, Sweden, And NATO: From 'Virtual' To Formal Allies? Washington DC: National Defense University, Institute for National Strategic Studies.

25 ABDI, The Ministry of Defense (2016) 'ABDI Bulletins 2/20I6', p. 26, <http://www.defmin.fi/files/3578/ABDI_(MTS)_December_2or6_ figures_in_english.pdf $>$ (accessed 29 April 2018).

26 ABDI, The Ministry of Defense (2008) 'ABDI Additional Survey Material,' p. I2, <http://www.defmin.fi/files/I322/raportti_in_english_o8_ nettiversio.pdf $>$ (accessed 30 April 20I8).

27 Prime Minister's Office (2013), 'Finnish Security and Defence Policy 2012,' p. $\quad 43, \quad<$ https://www.bbn.gov.pl/ftp/dok/o7/FIN_Finnish_Security_ Defence_Policy_2OI2_Government_Report.pdf $>$ (accessed I May 20I8). 
28 KristianÅtland(20I6), 'NorthEuropeanSecurityafter the UkraineConflict,' Defense \& Security Analysis 32(2), doi: Io.Io80/I475I798.20I6.II60484; Heather Saul (2014), 'Finland scrambles jets after two Russian aircrafts 'violate airspace', Independent, 22 May, available at: <https://www. independent.co.uk/news/world/europe/finland-scrambles-jets-aftertwo-russian-aircrafts-violate-airspace-941554I.html> (accessed I May 2018); Defense News (2015), 'New Finnish Gov't Expected to Hike Spending,' <https://www.defensenews.com/pentagon/2015/04/26/newfinnish-gov-t-expected-to-hike-spending/> (accessed I May 20I8); Körber Stiftung (2014), 'Finland's Prime Minister Alexander Stubb speaks in Berlin,' <https://www.koerber-stiftung.de/en/finlands-prime-ministeralexander-stubb-speaks-in-berlin-756> (accessed I May 20I8).

29 Finnish Government (2015), 'Finland, a land of solutions. Strategic Programme of Prime Minister Juha Sipilä's Government,' <https:// valtioneuvosto.fi/en/sipila/government-programme> (accessed I2 August 20I8).

30 Christopher S. Chivvis et al. (20I7), NATO's Northeastern Flank: Emerging Opportunities for Engagement, Santa Monica, Calif.: RAND Corporation, pp. I86-I87.

3I Tapio Raunio (20I8), 'Continuity in Finland as Sauli Niinistö is re-elected as President.', EUROPP, 3I January, available at: <http://blogs.lse.ac.uk/ europpblog/2018/or/3I/continuity-in-finland-as-sauli-niinisto-is-reelected-as-president/> (accessed 4 May 20I8).

32 The party's vision is that the country should become a member by 2025, but it also stated that "it is open to a process which will aim at Finland's membership of NATO. In this process, a broad discussion, a thoroughgoing analysis of security consequences and geopolitical impacts, and popular support will be needed." See Svenska folkpartiet (20I6), 'Ett mänskligt och framgångsrikt Finland,' pp. 29-30, <http:// www.sfp.fi/sites/default/files/Partiprogram_2or6.pdf> (accessed 5 May 2018).

33 Supporters of NATO accession are the most numerous (over 40 percent) among voters for the National Coalition Party (ABDI, The Ministry of Defense (20I7) 'Finn's Opinions on Foreign and Security Policy, National Defense and Security', pp. 30-3I; Uusi Suomi (2018), 'IL-US-kysely: Jo 48 \% suomalaisista hyväksyy sotilasyhteistyön syventämisen USA:n ja Naton kanssa,' <https://www.uusisuomi.fi/kotimaa/250665-il-us-kysely48-suomalaisista-hyvaksyy-sotilasyhteistyon-syventamisen-usan-janaton> (accessed 3I July 20I8); Reuters (20I7), 'Joining NATO would help Finland's security but unlikely for now: finance minister,' <https:// www.reuters.com/article/us-finland-nato-financeminister/joining-natowould-help-finlands-security-but-unlikely-for-now-finance-ministeridUSKBNiDT2ON $>$ (accessed 5 May 20I8).

34 Prime Minister's Office (2017), 'Government's Defence Report,' p. I4, <https://www.defmin.fi/files/3688/Jo7_20I7_Governments_Defence_ Report_Eng_PLM_I602I7.pdf> (accessed I November 2018).

35 Ministry of Defense (2018a), 'Puolustusministeriön tulevaisuuskatsaus: Turvallisuus ja puolustus - suomalaisen hyvinvoinnin kivijalka,' p. Io, <http://urn.fi/URN:ISBN:978-952-287-593-8> (accessed I2 August 20I8).

36 Ministry of Defense (2018a), pp. I5-16.

37 ABDI (20I7), p. 32, <http://www.defmin.fi/files/4062/Finns_opinions_
Lucie

Zimmermanová

Zdeněk Kř́íž 
on_Foreign_and_Security_Policy_National_defence_and_security_ november_20I7.pdf> (accessed I November 20I8).

38 Gordon F. Sander (20I4), 'Could Putin's Russia push neutral Finland into NATO's arms?' The Christian Science Monitor, I5 October, available at: <https://www.csmonitor.com/World/Europe/20I4/IOI5/Could-Putin-sRussia-push-neutral-Finland-into-NATO-s-arms> (accessed I May 20I8).

I/2020 39 ABDI (20I7), pp. 30-3I.

40 Yle (20I7a), 'Poll: $59 \%$ of Finns opposed to joining NATO', <https:// yle.fi/uutiset/osasto/news/poll_59_of_finns_opposed_to_joining_ nato/99I74I8> (accessed II August 20I8).

4I Yle (20I7b), 'Yle poll: Only a fifth of Finns back NATO membership,' <https://yle.fi/uutiset/osasto/news/yle_poll_only_a_fifth_of_finns_ back_nato_membership/9974703> (accessed 4 May 2018).

42 Uusi Suomi (2018).

43 ABDI (20I7), p. 30.

44 Raunio (20I8); Statistics Finland (20I8), 'Sauli Niinistö was elected President in the first election in 2018,' <https://www.stat.fi/til/pvaa/2or8/ pvaa_20I8_20I8-oI-30_tie_oor_en.html> (accessed 23 September 20I8).

45 Matti Pessu (20I7), What non-alignment? Finland's security and defense policy stems from partnerships, Helsinki: The Finnish Institute for International Affairs, available at: <https://www.fiia.fi/ en/publication/finlands-security-and-defence-policy-stems-frompartnerships?read\#viiteI> (accessed 2 May 20I8).

46 Nordenman (20I4); Ministry of Defense (2018b), 'NATO,' <https://www. defmin.fi/en/tasks_and_activities/defence_policy/nato> (accessed I November 2018).

47 Ministry of Defense (2014), 'Minister of Defence Carl Haglund at The Atlantic Council of the United States', <https://www.defmin.fi/en/ topical/press_releases/20I4/minister_of_defence_carl_haglund_at_ the_atlantic_council_of_the_united_states.5749.news $>$ (accessed I November 20I8); Stefan Forss and Pekka Holopainen (2015), Breaking the Nordic Defense Deadlock. The U.S. Army War College Strategic Studies Institute, p. 33.

48 Forss and Holopainen (2015), p. x.

49 Ilmavoimat, Air Force Command (2017) 'Ruska I7: a Succesful [sic] Test of Finland's Air Defense,' <https://ilmavoimat.fi/en/article/-/asset_ publisher/ruska-I7-ilmaoperaatioharjoitus-on-saatu-paatokseen> (accessed 2I October 2018).

50 Office of the President of the Republic of Finland (20I7), 'President Niinistö in Washington: Security the top theme of talks', <http://www.president. fi/public/default.aspx contentid $=365693$ \& nodeid $=44807$ \& contentlan $=2 \&$ culture $=$ en-US $>$ (accessed I November 20I8).

$5 \mathrm{I}$ Yle $(2017 \mathrm{c})$, 'Finland making plans to host large-scale joint military exercises,' <https://yle.fi/uutiset/osasto/news/finland_making_plans_ to_host_large-scale_joint_military_exercises/9916962> (accessed I ovember 20I8).

52 Yle (20I7d), 'Finland invites USA to join main military exercises,' < https:// yle.fi/uutiset/osasto/news/finland_invites_usa_to_join_main_military_ exercises/9920370> (accessed I November 2018).

53 Ministry of Defense (2018c), 'Statement of Intent,' <https://www.defmin. fi/en/publications/statement_of_intent> (accessed I November 2018). 
54 Paula Vilén (2018), 'Kunnialaukaukset saattelivat Suomen, Ruotsin ja USA:n tiiviimpään puolustusyhteistyöhön: 'Viemme sotilasyhteistyömme seuraavalle tasolle' Yle, 9 May, available at: <https:// yle.fi/uutiset/3-Iorg6763>. Accessed I November 2018.

55 Yle (2018), 'Finland, Sweden and US deepen defence cooperation in Washington, 2018,' <https://yle.fi/uutiset/osasto/news/finland_sweden_ and_us_deepen_defence_cooperation_in_washington/Ior95665> (accessed I November 20I8).

56 US Department of Defense (2018), 'Secretary Mattis Hosts an Armed Forces Full Honor Arrival Welcoming Finland Minister of Defence Jussi Niinistö and Sweden Minister of Defence Peter Hultqvist to the Pentagon,' <https://www.defense.gov/News/ Transcripts/Transcript-View/Article/I5I5540/secretary-mattishosts-an-armed-forces-full-honor-arrival-welcoming-finlandmin/> (accessed II August 2018).

57 Yle (20I6b), 'Finnish, Swedish leaders invited into 'inner circle' at NATO summit,' <https://yle.fi/uutiset/osasto/news/finnish_swedish_leaders_ invited_into_inner_circle_at_nato_summit/9002688> (accessed 25 October 2018).

58 René Nyberg (2016), The Line in the Sand: Finland and the Unpredictable Neighbor, Brussels: Carnegie Europe, available at: <http://carnegieeurope. $\mathrm{eu} /$ strategiceurope/64509> (accessed I November 2018).

59 Bergquist et al. (2016), pp. 7-8.

60 President of Russia (2018), 'Joint news conference with President of Finland Sauli Niinistö, <http://en.kremlin.ru/events/president/ news/58347> (accessed I November 2018).

6I Bergquist et al. (2016), p. 47.

62 Prime Minister's Office (2013).

63 Prime Minister's Office (20I6), 'Government Report on Finnish Foreign and Security Policy,' p. II, <http://valtioneuvosto.fi/ documents/Io6I6/I986338/VNKJo920i6+en.pdf/b33c3703-29f4-4ccea9io-bo5e32b676b9> (accessed I May 20I8).

64 Prime Minister's Office (2016), p. 24.

65 Prime Minister's Office (2017), pp. 8-I4.

66 Chivvis et al. (20I7), p. I95; Domisse (20I6); Jaakko J. Jääskeläinen et al. (2018), 'Finland's Dependence on Russian Energy', Sustainability Io(Io), 3445, doi: I0.3390/suioio3445.

67 Planeringskommissionen för försvarsinformation (2016), 'Finländarnas åsikter om utrikes- och säkerhetspolitiken, försvaret och säkerheten,' <http://julkaisut.valtioneuvosto.fi/bitstream/handle/Ioo24/790I2/ MTS_taitto_ruotsi_NETTI.pdf?sequence $=$ I\&isAllowed $=y>$ (accessed I November 20I8).

68 ABDI (20I7), p. 36.

69 Uusi Suomi (2018)

70 Kristi Raik et al. (2015), Pushed together by external forces? The foreign and security policies of Estonia and Finland in the context of the Ukraine crisis, Helsinki: The Finnish Institute of International Affairs, available at: <https://www.fiia.fi/en/publication/pushed-together-by-externalforces?read $>$ (accessed 2 May 20I8).

7I Yle (20I6a), 'Finnish security expert: NATO troops in Baltic countries only symbolic gesture,' <https://yle.fi/uutiset/osasto/news/finnish_ 
security_expert_nato_troops_in_baltic_countries_only_symbolic_ gesture/90I47I3> (accessed I November 2018).

72 Domisse (2016).

73 Dan Ekholm (20I8), 'Presidentti Niinistö saksalaislehden haastattelussa: Pitäisi olla todella varovainen kun tapaa Putinin,' Yle, I5 September, CEJISS available at: <https://yle.fi/uutiset/3-I0406439> (accessed 23 September I/2O2O 20I8). 